\title{
Proton pump inhibitors: How appropriate?
}

\author{
Daniel C Sadowski MD FRCPC
}

$T^{t}$ he introduction of omeprazole to the Canadian prescription drug market in 1989 heralded the beginning of a revolution in the treatment of acid peptic disease. The proton pump inhibitor (PPI) drug class now accounts for substantial expenditures in all Canadian pharmaceutical formularies. Understandably, the widespread use of these drugs has spurred questions regarding the appropriateness of PPI use.

In this issue of The Canadian Journal of Gastroenterology, Gregoire and colleagues (pages 673-677) present a retrospective review of PPI prescribing patterns in Quebec seniors with the use of a prescription and medical services claims database. PPI prescriptions were considered to be appropriate if the user had an upper gastrointestinal endoscopy in the previous six months, if the PPI was dispensed as part of an eradication regimen for Helicobacter pylori, or if the PPI was preceded by a prescription for an $\mathrm{H}_{2}$ receptor antagonist or prokinetic drug within the previous six months. Concurrent $\mathrm{H}_{2}$ receptor antagonist use was deemed to be inappropriate. Using these criteria, the authors concluded that only $54.7 \%$ of first time omeprazole prescriptions in Quebec were appropriate.

How valid are the results of this study when viewed from the clinical arena? The answer is largely determined by the definitions used for appropriateness. Utilization studies derived from medical service databases must define appropriateness in ways that can be readily measured by the database. This approach has the potential to identify overly restrictive criteria, which may be imperfect reflections of appropriate clinical care. What is appropriate PPI use according to current standards of good clinical practice? The weight of evidence currently supports the use of PPIs in the following situations: for prophylaxis of nonsteroidal anti-inflammatory drug-induced gastropathy; as part of an antibiotic regimen for $\mathrm{H}$ pylori eradication; for the treatment of refractory peptic ulcer disease; for the treatment of Zollinger-Ellison syndrome and other hypersecretory states; and for the treatment of symptomatically severe reflux or endoscopically proven erosive esophagitis.

More controversial is the use of PPIs as initial therapy for uninvestigated dyspepsia and gastroesophageal reflux symp- toms. There is good evidence that PPIs are superior to $\mathrm{H}_{2}$ blockers in the treatment of dyspepsia at the primary care level (1-3). As well, empirical drug treatment as opposed to endoscopy appears to result in lower medical costs but equal effectiveness (4). For gastroesophageal reflux, the timehonoured 'step-up' therapy has been challenged. A 'stepdown' approach (beginning with PPIs and stepping down to $\mathrm{H}_{2}$ receptor antagonists) or 'on demand' therapy has been advocated by some (5).

Until recently, concomitant use of $\mathrm{H}_{2}$ receptor antagonists and PPIs has been thought to be redundant and wasteful. However, recent observations have noted that control of nocturnal acid secretion may be inadequate in patients with refractory gastroesophageal reflux disease. Concomitant use of both $\mathrm{H}_{2}$ receptor antagonists at bedtime and PPIs during the waking hours may offer better control of acid secretion in this patient group $(6,7)$.

The above observations demonstrate the highly fluid nature of current medical opinion regarding appropriate use of the PPI drug class. While utilization studies such as the one by Gregoire et al are provocative, I submit that suitable criteria for appropriate PPI use remain to be defined.

\section{REFERENCES}

1. Jones RH, Baxter G. Lansoprazole $30 \mathrm{mg}$ daily versus ranitidine $150 \mathrm{mg}$ b.d. in the treatment of acid-related dyspepsia in general practice. Aliment Pharmacol Ther 1997;11:541-6.

2. Hunt RH. Importance of $\mathrm{pH}$ control in the management of GERD. Arch Intern Med 1999;159:649-57.

3. Festen HP, Schenk E, Tan G, Snel P, Nelis F. Omeprazole versus high-dose ranitidine in mild gastroesophageal reflux disease: short- and long-term treatment. The Dutch Reflux Study Group. Am J Gastroenterol 1999;94:931-6.

4. Laheij RJ, Severens JL, Van de Lisdonk EH, Verbeek AL, Jansen JB. Randomized controlled trial of omeprazole or endoscopy in patients with persistent dyspepsia: a cost-effectiveness analysis. Aliment Pharmacol Ther 1998;12:1249-56.

5. Nielsen OH, Vainer B, Madsen SM, Seidelin JB, Heegaard NH. Established and emerging biological activity markers of inflammatory bowel disease. Am J Gastroenterol 2000;95:359-67.

6. Orr WC, Harnish MJ. Sleep-related gastro-oesophageal reflux: provocation with a late evening meal and treatment with acid suppression. Aliment Pharmacol Ther 1998;12:1033-8.

7. Peghini PL, Katz PO, Castell DO. Ranitidine controls nocturnal gastric acid breakthrough on omeprazole: a controlled study in normal subjects. Gastroenterology 1998;115:1335-9.

\footnotetext{
Division of Gastroenterology, Royal Alexandra Hospital, Edmonton, Alberta

Correspondence: Dr DC Sadowski, Suite 310 Hys Centre, 11010 - 101 Street, Edmonton, Alberta T6H 4B9. Telephone 780-421-1029,

fax 780-425-5533, e-mail dan.sadowski@ualberta.ca
} 


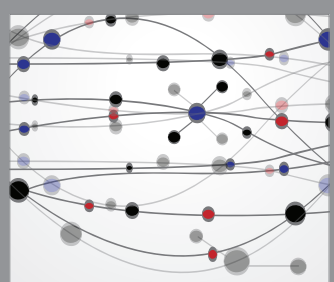

The Scientific World Journal
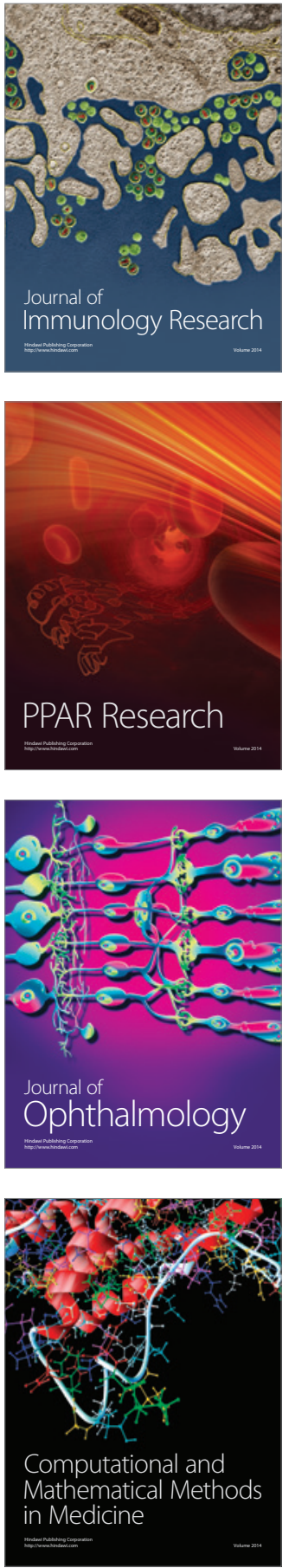

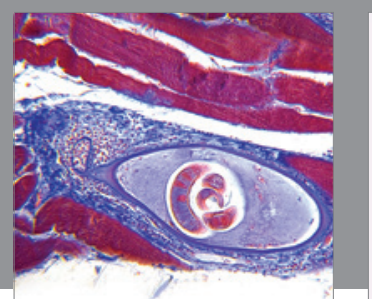

Gastroenterology Research and Practice

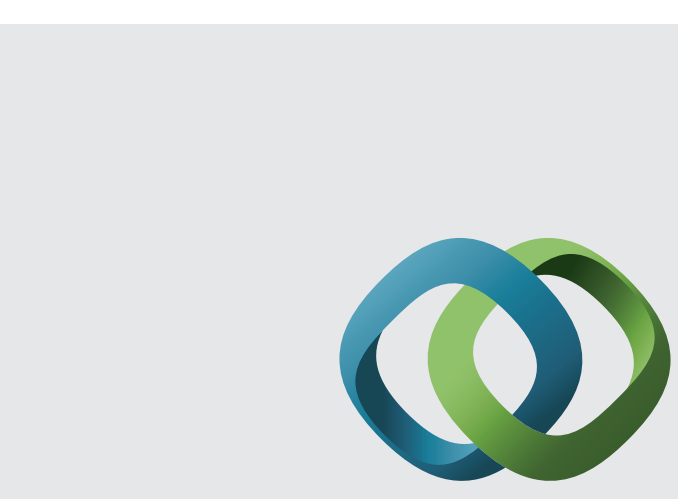

\section{Hindawi}

Submit your manuscripts at

http://www.hindawi.com
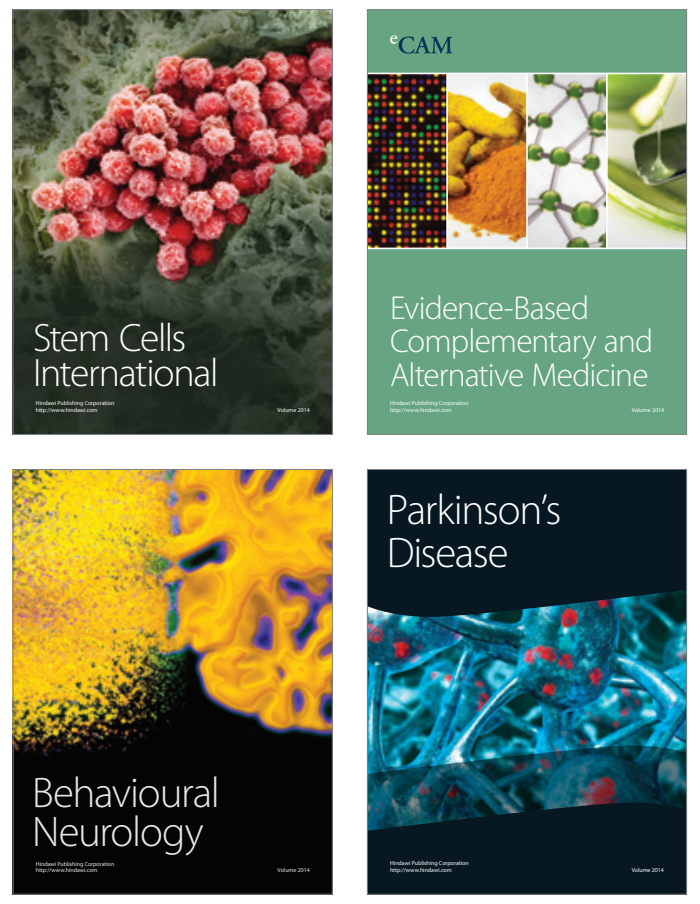
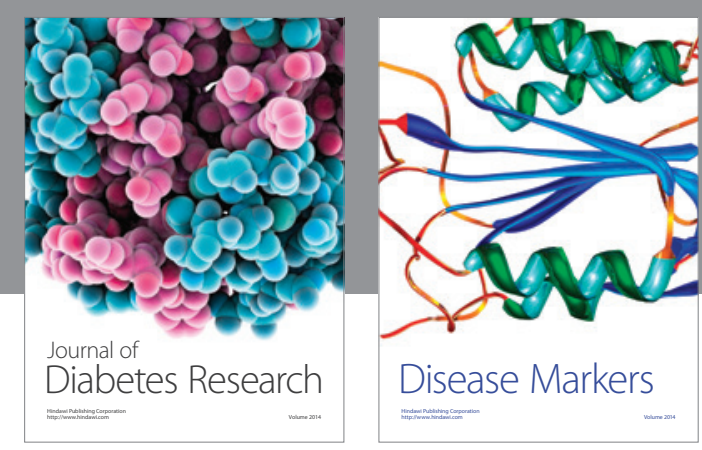

Disease Markers
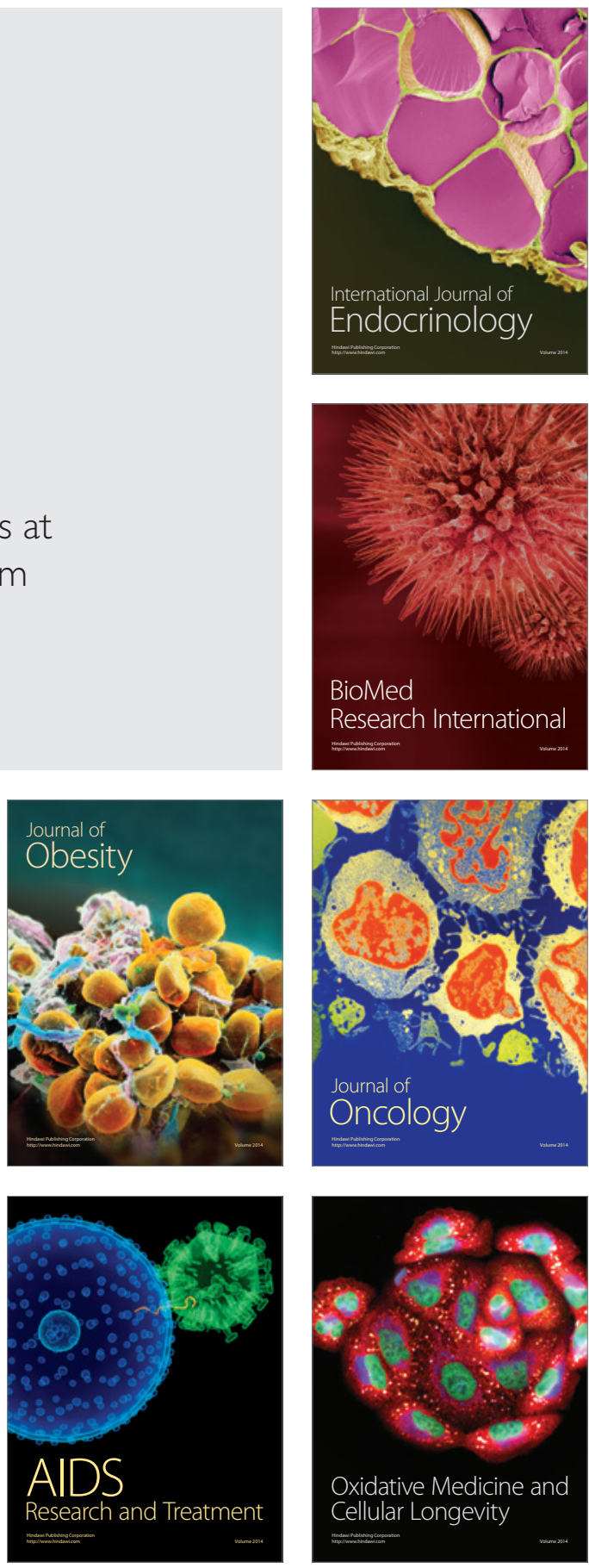